\section{AZ IFRS 17 HATÁSAI A BIZTOSÍTÓK ÜZLETI MÜKÖDÉSÉRE ÉS PÉNZÜGYI EREDMÉNYÉRE}

Árendás Ákos Tuzson, Orbán Barbara, Urbán Dóra (a Deloitte Zrt. Aktuáriusiés Biztositási Megoldások csapatának szenior tanácsadó aktuáriusai)

\section{ÖSSZEFOGLALÓ}

Ahogy azt a közelmúltban bevezetett EU-szintű és magyar biztosítási piaci szabályozások (például Szolvencia II, IDD, PRIIPs vagy éppen az etikus életbiztosítási koncepció) esetében már megszokhattuk, az IFRS 17 sem csupán a biztosítók müködésének egyes területeit érinti, hanem bevezetése a szervezet több funkciójára is hatással van. Egy új pénzügyi szabályozásnak való megfelelés kapcsán nemcsak a módszertan megértése, hanem az üzletvitelre gyakorolt hatásának feltérképezése is rengeteg kihívást tartogat. Egy összetett üzleti és pénzügyi hatáselemzés sok esetben rávilágít arra, hogy az IFRS 17 bevezetésének sikerességéhez nem lehet elég korán kezdeni a felkészülést. Cikkünkben arra törekszünk, hogy az általános biztosítói üzletvitelre várhatóan hatással lévő követelményekre felhívjuk a figyelmet.

\section{SUMMARY}

Similarly to the recent wave of EU and Hungarian regulations (such as Solvency II Directive, IDD, PRIIPs or the ethical life insurance concept), IFRS 17 affects not only a few areas of business operations that insurers run, but also several organizational functions they are operated by. To comply with a new financial regulation like IFRS 17, not only the profound understanding of the methodology, but the completion of a thorough business and financial impact assessment is challenging. Most of the time the outcome of such business and financial impact assessment highlights that the compliance with IFRS 17 would require more time and effort than one would normally expect. Our article aims at pointing out, but not limited to, the requirements those are expected to affect insurance business operations to the greatest extent.

Kulcsszavak: IFRS 17, üzleti hatáselemzés, pénzügyi hatáselemzés

Keywords: IFRS 17, business impact assessment, financial impact assessment

JEL: G22, M48

DOI: $10.18530 /$ BK.2018.3.58

http://dx.doi.org/1018530/BK.2018.3.58
Tapasztalataink alapján a piac egy részének körében elterjedt megközelítés, hogy a Szolvencia II-nek megfelelő, már meglévő folyamatok eleget tesznek az IFRS 17 (a továbbiakban: Standard vagy IFRS 17 Standard) legtöbb követelményének. Bár sok esetben a jelenleg alkalmazott megoldásokból érdemes kiindulni, a teljes megfeleléshez ennél jóval több erőfeszitésre lesz szükség. Elsőként szeretnénk eloszlatni néhány tévedést az IFRS 17 implementációjával kapcsolatban a teljesség igénye nélkül.

\section{0 tévhit az IFRS 17 bevezetése kapcsán}

1. Mivel az IFRS 17 azzal a céllal készült, hogy következetes és elvi megalapozottságú számviteli szabályokat határozzon meg a biztosítási szerződésekre vonatkozóan, így jóformán csak a számviteli és aktuáriusi területet érinti annak jövőbeli alkalmazása.

Téves következtetés, hiszen a következőkben rávilágítunk számos olyan területre, amely aktuáriusi, IT, illetve humán erőforrás szempontból biztosan érintetté válik.

2. A Szolvencia II már meglévő folyamatai és módszertani megvalósítása néhány kisebb módosítással átemelhetők.

Téves elgondolás, hiszen már ott eltér a két rezsim követelményrendszere, hogy a nem veszteséges szerződéscsoportokat milyen dátumon kell először értékelni. Igaz ugyan, hogy a biztosítási szerződés definíciója, a szerződéshatárok meghatározása vagy éppen a figyelembe veendő költségek köre (például befektetési tevékenységhez kapcsolódó költségek, szerzési költségek stb.) csak kisebb mértékben módosulnak a Szolvencia II-höz képest, azonban az IFRS 17 számos olyan új megközelítést, eljárást tartalmaz, amelyek egyáltalán nem léteznek a Szolvencia II keretein belül. Az aktuáriusi kalkulációk során alkalmazandó eltérő granularitási szint ${ }^{1}$ és a fent említett értékelési dátumok miatti eltérések szintén kellő odafigyelést igényelnek.

3. A szerződéscsoportok létrehozása egyszerü, homogén kockázati csoportok képzését igényli.

A Standard szerint ennél mélyebb elemzést igényel a szerződéscsoportok előállítása, mivel nem csak az egymáshoz hasonló kockázatok alapján történik a besorolás. Egy komplett klaszszifikációs folyamatot kell kialakítani és dokumentálni, aminek során a szerződések bekerülési időpontja, kockázati tulajdonsága és veszteségessége a fóbb szempontok. Utóbbival kapcsolatos a következő pont is.

4. A szerződések veszteségességi szintjének megállapítása a szerződéscsoport bekerülése előtt ${ }^{2}$ egyszerűen beilleszthető a beszámolókészitési folyamatba.

A szerződéscsoportok meghatározásának egy olyan eleméről beszélünk, amelyet a biztosítónak rendszeresen el kell végeznie minden beszámolókészítéskor az új szerződésekre, valamint azokra a szerződésekre, amelyek az előző beszámolókészitéskor elvégzett veszteségességi szint meghatározása során nyereségesnek bizonyultak, de a későbbi kezdet miatt még nem kerültek bemutatásra. Tekintve, hogy a tesztet szerződés szinten kell végrehajtani, annak implementálása a biztosító folyamatába az IT rendszerekre és az erőforrás-kapacitásra is nagy hatással lesz. Éppen ebből kifolyólag annak kérdése is felmerül, hogy a beszámolókészítés során ezt az új folyamatot 
hova helyezze el a biztosító, például az értékelés előtt a zárási folyamatban vagy esetleg egy, a zárási folyamatot megelőzően a priori veszteségességi indikátorok felállításával készüljön a teszt. Utóbbi esetben elvárás a veszteségességi indikátorok rendszeres felülvizsgálata, ami hasonlóan jelentős erőforrás-igényű feladat a biztosító számára.

5. A szerződésekértékelése, amit minden beszámolókészitéskor a teljes szerződésállományra vonatkozóan el kell végezni, a meglévő IT rendszerek kapacitását nem növeli jelentősen, és nem igányel IT beavatkozást a számítások elvégzése.

Az értékelés elvégzéséhez jóval részletesebb adathalmazra (mivel a pénzügyi beszámolóban bemutatandó elemek száma jelentősen megnövekszik), új adattípusokra, új részfolyamatokra (pl. szerződések veszteségességi szintjének megállapítása), valamint nagyobb számítási és adattárolási kapacitásra lesz szükség.

6. Nem-életbiztositási ágazat esetében a pénzáramok kárkifutási háromszög (kárbekövetkezési periódus) alapú meghatározása az IFRS 17 szerinti beszámoló készítésekor gond nélkül alkalmazható.

A szerződéscsoportok meghatározása során a kohorszokra ${ }^{3}$ való felosztásból fakadóan (azaz hogy egy kohorszba csak olyan szerződések tartozhatnak, amelyek kibocsátása között egy év vagy annál kevesebb idő telik el) érdemes megfontolni milyen megoldással (például allokációs módszerrel) lehet elkülöníteni a pénzáramokat, amennyiben azok eltérő szerződéscsoportba tartozó szerződésekhez kapcsolódnak.

7. A meglévő aktuáriusi szoftverek minimális módosítással vagy fejlesztéssel képesek a megfelelő teljesítési pénzáramokat előállítani.

Ezt cáfoló példaként lehet említeni a nem-életbiztosítási szerződések jövőbeli pénzáramainak diszkontálását, a szerződéses szolgáltatási marzsot ${ }^{4}(\mathrm{CSM})$ vagy a veszteség komponens ${ }^{5}(\mathrm{LC})$, illetve a kockázati kiigazítás kiszámítását szerződéscsoportonként. Érdemes időben megvizsgálni, hogy a biztosító által használt meglévő aktuáriusi szoftver képessé tehető-e az előbb felsorolt tételek meghatározására, vagy esetleg az aktuáriusi szoftveren kívül más IT platformon szükséges azokat számolni, és végül a beszámolókészítő rendszerrel összekötni. A diszkontálás esetében fontos kihívás még a felhasznált diszkontgörbék elöállításának kialakítása, ugyanis ebben a tekintetben az IFRS 17 jelentősen túlmutat (különböző diszkontgörbe alkalmazása különböző kötelezettség pénzáram kategóriákra, éven belüli súlyozott diszkontgörbe) a jelenlegi, például Szolvencia II során alkalmazott működésen.

8. A tartott viszontbiztosítási szerződések értékelése nem tartogat jelentős kihívásokat. Az egyik kihívást a viszontbiztosítási treaty ${ }^{6}$ alá tartozó olyan szerződések pénzáramainak megbecslése jelentheti, amelyeket még nem kötött meg a biztositó. ${ }^{7}$ Ehhez érdemes végiggondolni, hogy az új szerzések tervszámaival hogyan lehet mindezt összehangba hozni. A másik kihívás az értékelések során alkalmazott feltételezések összhangban való alkalmazása a viszontbiztosítási treaty, valamint az az alá tartozó szerzödések között. ${ }^{8}$ A harmadik kihívást a pénzáramok becslése során a viszontbiztosító partnerek nem-teljesítési kockázatának figyelembevétele jelentheti. Ehhez kapcsolódóan fontos még kiemelni a viszontbiztosításokhoz kapcsolódó adatok megfelelően automatizált összegyüjtését és azok tárolását, ami közvetett módon elengedhetetlen ahhoz, hogy a Standard fenti követelményeinek eleget tehessen a biztosító.

9. A biztosító KPI-okon („key performance indicator”) alapuló juttatási sémákat nem érinti a Standard.

Érdemes elemezni azokat a juttatási sémákat, amelyek a Standard implementációja előtt a biztosító díjbevételén vagy eredményén alapulnak, hiszen a beszámolóváltás után a bevétel és a profit meghatározása változik.

10. A zárási folyamat átalakítása kimerül a jelenlegi riportálási követelményeken felüli, új elemekre (például kockázati kiigazítás, CSM, veszteség komponens) vonatkozó számítások elvégzésével és azok beemelésével a folyamatba.

A biztositó zárási folyamatának átalakításakor fontos tényező az elvégzendő feladatokra maximálisan allokálható idő. Ebből kifolyólag nemcsak a fenti számítások beemelését kell figyelembe venni a zárási procedúra során, hanem a szerződésállomány-számításhoz elvárt granularitási szintjét. Gondolhatunk itt például arra, hogy a Standard engedi a szerződéscsoportszinttől eltérő, magasabb granularitási szintű számítások elvégzését, ha utána az eredményeket úira a jelentéstételhez elvárt szintre bontja le a biztosító. Ezzel természetesen megfelelő allokációs módszer kialakítása szükséges, amihez ellenőrzési pontok beépítése is elengedhetetlen. Bár a magasabb szintű adathalmazzal történő számítások időt spórolhatnak meg, nem árt a teljes folyamat előzetes átvilágítása és átgondolása.

Az IFRS 17 Standard nem csupán az aktuáriusi és pénzügyi területek számára fog változást, új feladatokat jelenteni.

Mindezek felismerése, az érintett területek azonosítása, a feladatok időbeni felvázolása kritikus fontosságú az új szabványnak történő megfelelés eléréséhez. Bár az IFRS 17 Standard legfőbb célja a biztosítók pénzügyi beszámolójának egységesítése, nem csupán az aktuáriusi és pénzügyi területek számára fog változást, új feladatokat jelenteni. A következőkben a Standard implementációjának a biztosítók működésére gyakorolt legfontosabb hatásait szeretnénk bemutatni.

\section{A biztosítói müködésre gyakorolt üzleti hatások}

\section{Stratégia és tervezés}

A biztosítóknak az IFRS 17 Standard bevezetését megelőző időszakban érdemes megfontolniuk, hogy a továbbiakban az IFRS-ek vagy a magyar Számviteli törvény szabályai alapján szeretnék az elsődleges pénzügyi beszámolójukat elkészíteni. Attól függően, hogy egy biztosító egyedi beszámolókészítés céljából alkalmazza az IFRS-t, vagy az anyavállalata számára készítendő jelentéscsomag részeként, más materialitási szintek vonatkoznak rá, ami hatással lehet az alkalmazni kívánt megoldás kiválasztására. A választás hatása jelentős, mivel ha az IFRS szerinti elsődleges beszámolóké- 
szítést választja a cég, mindenképp szükség lesz többek között az egyéni és cégszintű teljesítmény mérésére használt mértékek, KPI-ok módosítására. Ezáltal az IT működés és a jelentési folyamatok is érintve lesznek. Az adózási hatásokkal is számolni kell, mivel az adóalap is az IFRS szerinti beszámoló alapján lesz meghatározva, valamint az áttérésre speciális adózási előírások vonatkoznak, amelyek bemutatása nem képezi e cikk részét. Az új, egyéni és cégszintü pénzügyi teljesítményt mérő mutatókat úgy kell meghatározni, hogy azok a korábban alkalmazott, például díjbevétel- vagy eredményalapú mérés helyett az IFRS 17 szerinti pénzügyi beszámoló elemein alapuljanak, illetve azokkal összhangban legyenek. Mivel a biztosítási díjbevétel és a profit meghatározása alapvetően megváltozik az IFRS 17 alatt, az ezeken a mutatókon alapuló juttatási sémákat is módosítani kell. Az új mérési módszer kialakításában figyelembe kell venni a biztosító hosszú távú pénzügyi és stratégiai céljait. A biztosító vezetőségének oktatása az új Standard követelményeire, hatásaira ezen okok miatt is kulcsfontosságú lesz. Érdemes többféle szimulációt végezni az IFRS 17 egyéni és cégszintű pénzügyi teljesítményre gyakorolt hatásának vizsgálatára, ezzel támogatva az új mérési rendszerek kialakítását.

Az elörejelzési folyamatokban, pénzügyi és stratégiai tervezésben is megjelenik az IFRS 17 hatása. A tervriportokat úgy kell módosítani, hogy azok az előzőekhez hasonlóan az új pénzügyi mutatókat is figyelembe vegyék. Fontos megjegyezni, hogy ezen okból az IFRS 17 szerinti új elemek definiálása, a folyamatok kialakítása már jóval az alkalmazási határidő előtt szükséges lehet.

Mivel a biztosítók pénzügyi beszámolója tartalmában és szerkezetében is megváltozik, fontos a változások megfelelő kommunikációja a cégtulajdonosok, befektetők számára. Az aktuáriusok feladatköre várhatóan kibővül az eredmények, beszámolóelemek menedzsment részére történő indoklásával és a változások hatásának ismertetésével.

\section{Emberi erőforrások és szervezeti felépítés}

Az új pénzügyi beszámoló készítésében és a zárási folyamatokban megnövekedett feladatok száma miatt szükség lesz a rendelkezésre álló erőforrások felmérésére a leginkább érintett aktuáriusi, számviteli és IT területeken. Nem elég csak a hatáselemzési és az implementációs szakaszra tervezni, a Standard hatályba lépése utáni éles működés során folyamatosan mủködtetni kell az újonnan kialakított kalkulációs folyamatokat, az előálló eredményeket pedig elemezni, monitorozni kell.

Ideális esetben az IFRS 17 hatása a szervezeti működésben is megjelenik, mivel a beszámoló előállításához a pénzügyi, számviteli, aktuáriusi és IT terület részéről szorosabb együttműködésre lesz szükség. A szakterületek közötti keresztfunkciók kialakítása hatékonyabbá teszi a beszámolókészítés folyamatát. A társterületeknek sokkal jobban meg kell érteniük egymás feladatait, az előállított eredményeket, valamint azok felhasználását a saját szakterületükön. Az új szabályozás egyik legnagyobb kihívása a területek munkájának összehangolásában, valamint a megfelelő tudással rendelkező szakértők megtalálásában, felkészítésében rejlik.

\section{IT rendszerek és adatok}

Az IFRS 17 implementációjának sikeres kivitelezése nagyban múlik a biztosító jelenlegi IT rendszereinek és folyamatainak felkészültségén, valamint az IT erőforrások pontos tervezésén. A szerződés-nyilvántartó és -kezelő (díj-, kár-, jutalékelemeket tartalmazó), aktuáriusi, számviteli, riportálási és egyéb biztosító specifikus IT rendszerek állapotának és jelenlegi funkcióinak, rendszerkapcsolatainak alapos feltérképezése a projekt egyik alapköve.

Az új pénzügyi beszámoló előállításához szükséges számítások végrehajtásához a szerződések jóval több adatára lesz szükség, mint jelenleg. Új adattípusokat kell definiálni, és az adatok struktúráján is változtatni kell. Például ahhoz, hogy a portfólió szerződéseit az IFRS 17 szerint csoportokba rendezzük, a szerződések profitabilitását egyenként meg kell állapítanunk, illetve a szerződések bekerülési időpontját ismernünk kell. Ha új adattípusokat definiálunk, a rendszereket fel kell készíteni azok tárolására, kezelésére. A már meglévő szerződések historikus adatainak előállítása vagy különböző IT rendszerekből való összegyűjtése problémás lehet. A szerződésadatok, aktuáriusi számítások eredményei, értékesítési adatok és díjak sokszor különálló rendszerekben vagy az architektúrán kívüli fájlokban (Excel, access, txt) vannak tárolva. A helyzet még komplexebb, ha a biztosító korábbi, már nem használt IT rendszereiből migrált adatok vannak, esetleg vásárolt portfólióval rendelkezik. Adatmigrációk esetén a már nem aktív (lejárt, visszavásárolt vagy megszűnt) szerződések esetén szokásos módszer, hogy a szerződés adatát nem migrálják át az új rendszerbe. Ebben az esetben az archív adatok kinyerése a már régóta nem használt IT rendszerekből nehézséget jelenthet.

Amennyiben a szükséges adatok rendelkezésre állnak, fontos azok konzisztenciájának, megbízhatóságának ellenőrzése. A historikus adatok minősége, formátuma, teljessége rendszerenként különbözhet. Szükség lehet az adatok tisztítására és egységesítésére ahhoz, hogy riportálási célokra fel tudjuk őket használni.

A biztosítóknak a 2019. év végi pénzügyi beszámolót már úgy kell elkészíteniük, ahogyan azt az IFRS 17 követelményei elvárják. A következő egyéves periódust nevezzük az átmenet („transition”) időszakának, amikor párhuzamosan be kell mutatni a régi és az új beszámoló szerint is a biztosító teljesítményét, így megkapjuk az IFRS 17-re való áttérés eredményre gyakorolt hatását. Az átmenetre a Standard három módszert ajánl fel: a teljes retrospektív, a módosított retrospektív és a „fair value” megközelítés közül portfóliónként kell választani. A megfelelő módszer kiválasztása a szükséges adatok rendelkezésre állásától fog függeni. Abban az esetben, ha nem a teljes retrospektív megközelítést alkalmazza a biztosító, döntését a beszámoló mellékletében alaposan meg kell indokolnia. Ez az indoklás nagyban IT érveken, az adatok elérhetőségén fog alapulni. 


\section{Folyamatok}

Az adatok mellett a másik nagy kihívás a rendszerek felkészítése lesz az IFRS 17-nek megfelelö folyamatok, kalkulációk elvégzésére. Gyakori tévhit, hogy a Szolvencia II megfeleléshez kialakított folyamatok megoldják ezt a kérdést. A következőkben bemutatjuk, hogy melyek azok a legfontosabb folyamatok, amelyek kialakítására vagy éppen a meglévő működés módosítására lesz szükségük a biztosítóknak. Fontos, hogy minden kialakított folyamat visszakövethető és auditálható módon dokumentálva legyen, a kapott eredményeket pedig tárolják el a rendszerek.

- Klasszifikáció: Amennyiben a biztosítási szerződés olyan befektetési vagy szolgáltatási elemet tartalmaz, amelyre a Standardban meghatározott feltételrendszer ${ }^{9}$ teljesül, azt kötelezően le kell választani a biztosításról, a nem leválasztandó elemeket pedig kötelezően együtt kell kezelni a főbiztosítással. Ez különbözik a Szolvencia II gondolatmenetétől, ahol kockázati alapon volt megközelítve a szerződések szétbontása. Szerződéskomponensenként meg kell állapítani, hogy melyik IFRS alkalmazandó az értékelésre (pl. IFRS 9 vagy IFRS 15). A szétválasztási folyamat termékfejlesztési szinten is eldőlhet, de bonyolultabb esetekben az algoritmust az IT rendszerekbe is implementálni kell.

- Csoportokba sorolás: A biztosító teljes portfólióját az IFRS 17-nek megfelelő csoportokba és portfóliókba kell sorolni. A folyamathoz egy olyan döntési algoritmust kell implementálni a szerződésfelvételi, szerződéskezelő vagy az aktuáriusi rendszerekbe, amely figyelembe veszi az adott szerződés bekerülési időpontját, kockázati tartalmát és profitabilitását. Ezen adatokra szerződésenként lesz szükségünk, és a profitabilitás kiszámítását is szerződésszinten kell elvégezni. Ehhez a jelenlegi profittesztekben használt módszerek használhatóak lesznek, a nehézséget a szerződésszintre átalakítás és a valós idejű számítások gyors elvégzése fogja okozni.

- Diszkontálás: A jövőbeli pénzáramokat olyan diszkontgörbével kell diszkontálni, amely a szerződés jövőbeli pénzáramainak karakterisztikáját tükrözi. A Szolvencia II által elvárt, EIOPA által közzétett kockázatmentes hozamgörbe alkalmazása már nem lesz elégséges. Az új diszkontgörbe megállapítása különösen azokban az esetekben lesz bonyolult, amikor a szerződés jövőbeli pénzárama a mögöttes eszközök hozamától függ. Emiatt a befektetéseket nyilvántartó és az aktuáriusi modelleket müködtető rendszerek is érintettek lesznek az új folyamat kialakításában.

- Kockázati kiigazítás: A pénzáramok meghatározásán felül a biztosítónak egy olyan kiigazítást kell alkalmaznia, amely a pénzáramok várható jelenértékén túl kompenzálja az azok bizonytalanságából adódó kockázatot. A Szolvencia II-nél bevezetett kockázati marzs megállapításának folyamata hasznosittható, de az IFRS 17 kevésbé ad konkrét megoldást a számítás folyamatára. A felajánlott módszerekről és a konfidenciaszint mértékéről a portfólió tulajdonságainak figyelembevételével kell a biztosítónak döntenie.

- CSM: a szerződések és szerződéscsoportok jövőbeli profitjának megállapítása teljesen új koncepció mentén történik az IFRS 17 alatt, ami mögött komplex számítások húzódnak. Az aktuáriusi rendszereket fel kell készíteni az új számításokra, valamint az adatok átadására a számviteli rendszerek felé. Amennyiben determinisztikus modellekkel nem oldható meg a szerződések értékelése, sztochasztikus módszerek alkalmazására is szükség lehet.

\section{IT architektúra}

Mivel az IFRS 17 alkalmazása során jóval több kalkulációra és azok párhuzamos futtatására lesz szükség, valamint a pénzügyi beszámolóban bemutatandó elemek száma jelentősen megnövekszik, célszerủ lehet a biztosítók IT architektúrájának újragondolása. Az Excel-alapú és manuális számításokkal, adatátadásokkal már nem lesznek hatékonyan teljesíthetőek az IFRS 17 követelményei. Különös nehézséget okozhat IT szempontból azátmenet, hiszen a teljes retrospektív átmeneti módszer alkalmazásakor az egész portfólió esetén meg kell adni a szerződések historikusan becsült pénzáramait a kezdeti bekerülés óta rendre minden beszámolókészitési időpontra, beleértve az azóta megszűnt szerződéseket is, majd így megállapítani a kezdeti CSM értékét. Automatizált folyamatok kialakításával az adatok előállítási, kezelési hatékonysága növekszik, ami elengedhetetlen lesz az új követelmények időben történő teljesítéséhez. Hasznos felmérni, hogy a meglévő rendszerek, folyamatok fejlesztése vagy akár egy teljesen új IT rendszer implementálása milyen költségeket okoz a biztositónak, akár belső fejlesztési kapacitásból, akár a piacon elérhető külső szolgáltatók által kínált lehetőségek megvásárlásával.

\section{【Különös nehézséget okozhat IT szempontból az átmenet.}

Az aktuáriusi zárási folyamat ideje jelentősen megnövekedhet az új folyamatok, kalkulációk elvégzésének hatására, ez különösen indokolja az automatizációk alkalmazását. A meglévő szerverek, aktuáriusi és számviteli szoftver licenszek számát át kell gondolni. A szerződésnyilvántartó, aktuáriusi, pénzügyi és számviteli IT rendszerek közötti interfészek módosítására is sor kerülhet, mivel a jelenleginél jóval nagyobb mennyiségű adat átadására lesz szükség az egyes rendszerek között, illetve az adatátadás irányában is lehet változás, függően a biztosító által alkalmazott folyamatoktól, módszerektől. Például az aktuáriusi rendszereknek információt kell kapniuk a múltbeli CSM értékéről, míg a pénzügyi és számviteli rendszereknek a kockázati kiigazítás és a CSM számított értékéről, valamint a diszkontgörbékről kell információval rendelkezniük a pénzügyi beszámoló és a hozzá kapcsolódó magyarázatok előállításához.

\section{Piaci kitekintés}

A magyar piac felkészültségéről tapasztalataink alapján általánosságban elmondható, hogy a legnagyobb problémát várhatóan az IT rendszerek szétszabdaltsága és nem komplex felépítése fogja okozni, emiatt a szükséges adatok elő́llítása problémás lehet.

A Szolvencia II-nél bevezetett elemek (szerződések határa, kockázati marzs, „, best estimate” pénzáramok) az európai biztosítóknak általánosságban segítséget jelentenek, ezek IFRS 17 kompatibilissá alakításával elérhető az új követelményeknek (szerződések határának IFRS 17 szerinti definíciója, kockázati kiigazítás, IFRS 17 pénzáramok) való megfelelés. Azon elemek esetében, amelyek nem változtak jelentősen az IFRS 4-hez képest (pl. szerződés definíciója), az implementáció várhatóan kis erőforrás-befektetéssel megoldható lesz. 
A brit biztosítók piacának elemzéséből (Deloitte UK kutatás, 2017. november) kiderül, hogy a legnagyobb erőforrásigény és -költség esetükben is az IFRS 17 által bevezetett új elemek előállításából fog adódni, valamint az új pénzügyi beszámoló és a hozzá kapcsolódó magyarázatok („disclosure”) generálása fogja őket kihívás elé állítani (1. ábra). Az élet- és nem-élet biztosítási ágakat külön vizsgálva elmondható, hogy a nem-élet ág felkészültségi szintje magasabb, ez a szerződések rövidtávúságának és az ebből adódó pénzáramok egyszerűbb felépítésének köszönhető.

\section{1. ábra: A brit biztositási piac IFRS 17 felkészültsége 2017 végén}

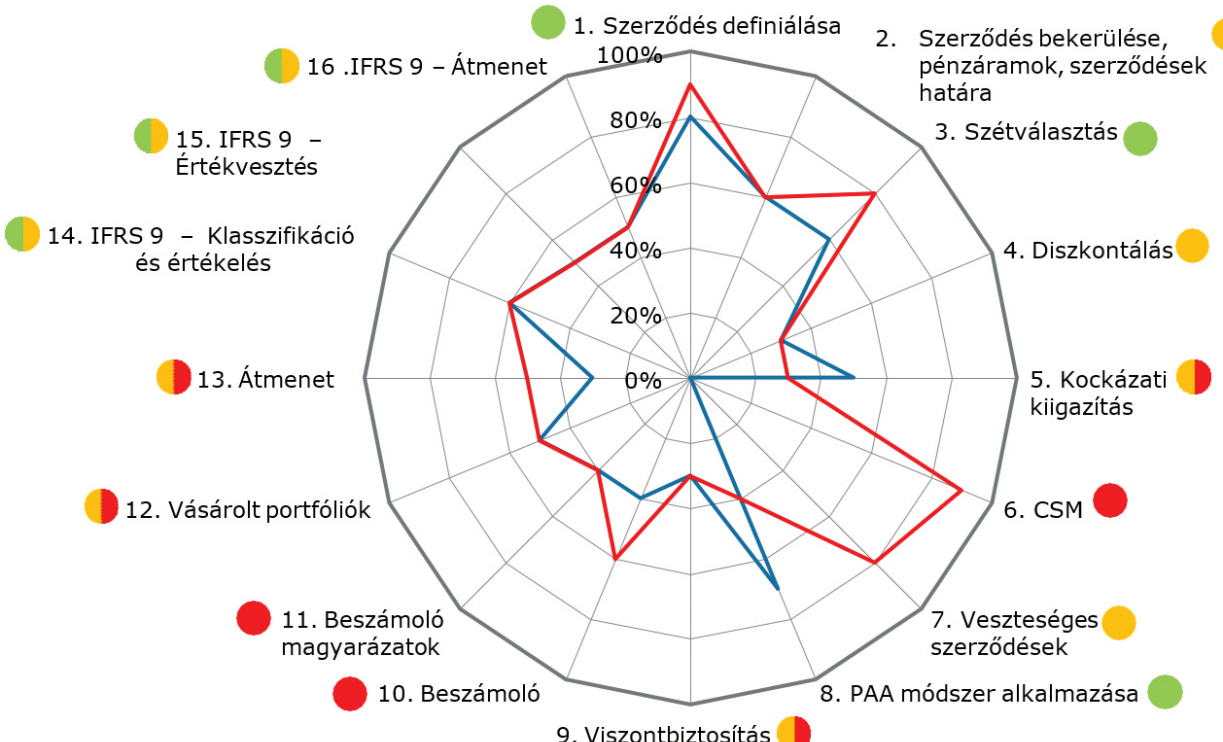

9. Viszontbiztosítás

\begin{tabular}{|c|c|}
\hline & \\
\hline & Jelentös munkát igényel, magas költséggel \\
\hline felada & $\begin{array}{l}\text { Közep } \\
\text { költsé }\end{array}$ \\
\hline & $\begin{array}{l}\text { Könnyen implementálható feladat, alacsony } \\
\text { költséggel }\end{array}$ \\
\hline $\begin{array}{l}\text { elkészültség } \\
\text { lenlegi } \\
\text { lapota IFRS } 17 \\
\text { makörönként }\end{array}$ & $\begin{array}{l}\text { —Életbiztositók jelenlegi felkészültsége } \\
\text { — Nem-élet biztositók jelenlegi felkészültsége }\end{array}$ \\
\hline
\end{tabular}

Forrás: Deloitte UK kutatás, 2017. november
A globális piacot tekintve az Economic Intelligence Unit (EIU) 2017-ben végzett kutatása adhat viszonyítási alapot, amelyet a Deloitte 2018-as biztosítási jelentésében publikált. A globális biztosítótársaságok részéről 340 fő biztosítási szakértő, vezető bevonásával végeztek felmérést annak felderítésére, hogy a biztosítók hogyan látják az IFRS 17 bevezetésére való felkészültségüket két és fél évvel az átmenet időszaka előtt. A főbb eredményeket az alábbiakban foglaljuk össze:

- A határidő teljesítése kritikus lesz: A globális társaságok képviselőinek 90 százaléka gondolja, hogy a 2021-es bevezetési határidőre meg fognak felelni az IFRS 17 követelményeinek. A regionális megoszlást tekintve az európai biztosítótársaságok felkészültebbnek tartják magukat a bevezetésre.

- Szzükséges a meglévő technológiák fejlesztése: A biztosítók 87 százaléka szerint a jelenleg használt IT rendszereiket fejleszteni kell annak érdekében, hogy a megnövekedett adatigényt és az új kalkulációkat el tudják végezni. Az adatok előállítását és rendszerezését jelölték meg a megkérdezettek a legnagyobb technológiai kihívásnak az IFRS 17 tekintetében.

- A bevezetés jelentős költséggel fog járni: A biztosítók jóval magasabb összköltséget várnak az implementáció elvégzésére, a szakemberek 35 százaléka több mint 50 millió eurós összköltséget becsül az implementáció elvégzésére a teljes cégcsoportjuk esetében, 2013-ban ugyanebben a körben végzett felmérésen ez az arány még csak 7 százalék volt.

- Az IFRS 17 előnyei kompenzálják a bevezetés magas költségeit: A biztosítók szakértőinek 93 százaléka úgy gondolja, hogy az új szabályozás hasznossága meghaladja a felmerülö költségeket, ez az arány 2013-ban csupán 21 százalék volt. Ez is bizonyítja, hogy az új Standard fontosságát fokozatosan ismeri fel a piac. A megkérdezettek az IFRS 17 alábbi három előnyét értékelik a leghasznosabbnak:

1. A pénzügyi beszámolók jobban tükrözik az üzleti teljesítményt.

2. A tőkepiacokon erősebb jelenlétet biztosít.

3. A termékfejlesztésekben jól felhasználhatóak az új információk.

- Az aktuáriusi és számviteli tudásra nagy szükség lesz, a területek közötti együttműködés elötérbe kerül:

Az együttműködés képességét ugyanolyan fontosságúra értékelték, mint az aktuáriusi szakértelmet. A vezetők egy része a pénzügyi és aktuáriusi területek integrációját tervezi. A legnagyobb kihívást abban látják, hogy a projekt végrehajtásához szükséges szakértői erőforrást megtalálják a munkaerőpiacon.

\section{A biztosítói eredményre gyakorolt pénzügyi hatások}

Mint ahogy azt már több ízben láthattuk cikkünkben, az új számviteli szabványra való átállás során rengeteg döntést kell hoznia a biztosítónak. A menedzsment feladata, hatásköre és felelössége lesz, hogy a lehetőségek közül meghatározza a használandó metódusokat. A hosszú távú hatások miatt érdemes alaposan felkészülni ezen döntések meghozatala előtt. 
Pénzügyi tekintetben több olyan releváns kérdés merül fel, amelyek egy számviteli rendszer változásakor érdekesek lehetnek, és ezek megválaszolása segítheti a vezetőket a döntéshozatal során. A legfontosabb kérdések közé tartoznak:

- átmenetkori hatás vizsgálata ${ }^{10}$,

- profit (adózás előtti eredmény) időbeli alakulása,

- CSM mértéke és főképp annak beszámolási időszakonkénti változásának dinamikája és mértéke.

Az új számviteli szabványra való átállás során rengeteg döntést kell hoznia a biztosítónak.

Az átmenetkori hatás lényegében az IFRS 4 szerinti tartalék és az IFRS 17 tartalék közötti különbség (amennyivel több az IFRS 4 tartalék szintje, annyi az átmenet hatása). Ez az átmenet dátumára ${ }^{11}$ nézve egyszeri tételként fog megjelenni a saját tőkében, így bizonyos tekintetben a későbbiekre nézve csak veszteségelnyelő képessége lesz. A profit tekintetében az a kezdeti benyomásunk, hogy az IFRS 17-es nyereség kiegyensúlyozottabb lesz az IFRS 4 szerinti nyereségnél, de vajon ez minden esetben (termék, választott értékelési módszertan stb.) így van? A CSM a biztosítói bevételek legfontosabb eleme, lényegében a jövőben várhatóan realizálható nyereség. Emiatt annak beszámolási időszakonkénti változása az időszak nyereségességéről adhat képet.

Ezen hatások számszerüsített eredményeire hatással lesznek olyan döntések, mint például:

- $\quad$ szerződések aggregációja (csoportok, kohorszok és portfólión belüli nyereségességi szint alapján),

- értékelési módszertanok közötti választások (BBA vagy VFA, BBA vagy PAA),

- diszkontráták változási hatásának elszámolása (egyéb átfogó jövedelemben ${ }^{12}$ vagy az eredménykimutatásban ${ }^{13}$ ),

- átmenetkor alkalmazandó módszer (teljes retrospektív, módosított retrospektív vagy valós érték megközelítés ${ }^{14}$ ).

Fontos a kapcsolat egyéb más standardokkal is. Az eszköz oldalra az IFRS 9 vonatkozik majd, kötelezettség oldalra az IFRS 17, és az IFRS 17 átállás keretében meghozott döntések és választások befolyással lehetnek az IFRS 9 szerinti üzleti modell meghatározására, mivel a pénzügyi eszközök értékelhetők amortizált bekerülési értéken vagy egyéb átfogó eredménnyel szemben valós értéken is.

Az egyes döntések előkészítése pontos és alapos számításokat igényel, azonban sok esetben mint ahogy arról korábban írtunk - erre nem feltétlenül állnak készen a biztosítótársaságok. A teljes felkészülés nagyon hosszú folyamat, és rengeteg fejlesztést igényelhet, azonban első lépésként ahhoz, hogy általános képet kaphassunk a várható változásokról, érdemes lehet különböző észszerü egyszerüsítések mellett elemezni azállományt. Egy ilyen hatáselemzés végrehaitása során amellett, hogy benyomásunk lesz mind a számítási folyamat komplexitásáról, mind a pénzügyi hatásokról, feltárhatunk olyan modellezési hibákat és adathiányosságokat, amelyek javítása és helyreállítása elengedhetetlen lesz a tényleges számításokhoz. A felmérés az átmenetkor alkalmazandó módszerekhez szükséges adatok elérhetőségét is felderít, így nagyban hozzájárul a döntés meghozatalához.
A következőkben bemutatunk egy lehetséges megoldást a pénzügyi hatáselemzésre, amelyben kitérünk arra is, hogy milyen egyszerüsítések és feltételezések mentén lehet viszonylag rövid idő alatt, első körben jól átfogó képet kapni a biztosítási portfólióra gyakorolt hatásokról.

\section{Esettanulmány}

A fentebb említett konkrét hatások bemutatásához célunk, hogy előállítsuk és összehasonlítsuk ugyanazon szerződésekre az IFRS 4 és IFRS 17 szerinti pénzügyi beszámolókat (mérleget, eredménykimutatást és adott esetben egyéb átfogó jövedelmet). Jelen esettanulmányban vegyes, kockázati és unit-linked életbiztosítási termékre vonatkozó eredményeket mutatunk be. Elsődlegesen most a két standard alapján számított profit közötti különbség kimutatására, valamint a CSM hosszú távú és éven belüli alakulására fókuszálunk. Azátmenetkori számítások tekintetében teljes retrospektív megközelítést alkalmaztunk.

A számítások egy általunk előállított minta biztosítási portfólió adatain alapulnak, a számszaki végeredmények helyett pedig inkább a hatások iránya, mértéke fontos jelen esetben, így bemutatásunkban arra koncentráltunk. Az eredmények és az azokból levonható konklúziók konkrét értékek nélkül is jól mutatják a hatások lényegét.

A számításokat Prophet 9-ben végeztük, az International Liability és IFRS 17 könyvtárak segítségével. A bemeneti adatok előkészítéséhez és az eredmények kiolvasásához MS SQL-t és MS Excelt használtunk, míg az eredmények hatékony és lényegre törő megjelenítése Power BI szoftverben történt.

\section{Alkalmazott egyszerüsítések}

Hatáselemzésünk során több olyan feltételezéssel is éltünk, melyek eredményre gyakorolt hatását külön-külön is vizsgálni lehetne, azonban a célunk eléréséhez - miszerint minél rövidebb idő alatt, minél komplexebb, valós képet kapjunk a várható hatásokról - az alábbi feltételezéseket, egyszerüsítéseket használtuk:

- Az eszköz oldal tekintetében mindent pénzeszközként ${ }^{15}$ kezeltünk, így ez egyfajta kiegyenlítő elemként ${ }^{16}$ jelenik meg a mérleg két oldala között.

- Terméktípustól függően általános értékelési modellt ${ }^{17}$ (GMM) vagy változó díjas megközelítést ${ }^{18}$ (VFA) alkalmaztunk.

- $\quad$ A szerződések aggregációja során a kohorszok megállapításánál az egy éven belül kezdődő, ugyanazon módozat alá eső szerződéseket tekintettük összetartozónak, azonban a szerződések veszteségességi szintjének megállapításánál(OCT) szerződés szinten nem vizsgáltuk a profitabilitást, és nem különítettük el a veszteséges szerződéseket, ugyanis előzetes elemzések során kiderült, hogy a portfóliónak elenyésző része érintett.

- Adatok hiányában a becsült és valós pénzáramok közötti eltéréssel nem számoltunk - sem díj, sem szerzési költségek esetén. 


\section{Feltételezések}

Ahhoz, hogy teljes retrospektív értékelést tudjunk alkalmazni a portfólióra, olyan feltételezéseket kell historikusan alkalmaznunk, amelyeket a megelőző értékelési időpontokban használtunk volna IFRS 17-es értékelésre. Ehhez megfelelőek lehetnek a kötelezettségmegfelelöségi teszthez ${ }^{19}$ (LAT) használt feltételezések. Mivel ezen adatok esetünkben rendelkezésre álltak, így a diszkontrátákra, mortalitásra, törlési rátákra, indexálás elfogadására vonatkozó feltételezések az éves LAT számításokból származnak.

\section{Számítások}

A konkrét pénzáramok előállításához a Prophet 9 IFRS 17 könyvtárát használtuk, ezeket egy meglévő tartalékolási modellből származó pénzárameredmények alapján töltöttük be. Megjegyezzük, hogy ezen eredmények származhatnak akár magából a Prophet-ből, azaz egy érvényben levő tartalékoló modellből, akár valamilyen külső rendszerből. A futások eredményeként kiolvashatóvá váltak mind az IFRS 4, mind az IFRS 17 szerinti beszámolók (mérleg és eredménykimutatás).

A számítások során nagyon gyakori, hogy nem a teljes portfólióra történik a hatáselemzés, azonban a végeredmények tekintetében sokszor a teljes kép az érdekes. Érdemes a nem modellezett és modellezett termékek között a profitstruktúra alapján kapcsolatokat keresni, és ezáltal elvégezni a vetítést, azonban figyelembe kell vennünk, hogy az IFRS 4 szerint nem annyira kiegyensúlyozott a profit alakulása, így például mindenképpen megfontolandó, hogy az adott állomány lejáratáig mennyi idő van hátra.

\section{Eredmények}

Jelen tanulmány legfontosabb tanulságaiként az alábbiakat emelhetjük ki.

\section{A nyereség alakulása}

Elsődleges megállapításunk, hogy ezen állomány esetén (mindhárom termék eredményeit összességében vizsgálva) az IFRS 17 szerinti profit (azaz az átfogó eredmény, ami az eredménykimutatás és az egyéb átfogó jövedelem összege) kiegyensúlyozottabb, kevésbé volatilis, mint az IFRS 4 szerint (2. ábra). Azonban a profitok alakulásáról elmondható, hogy termékenként nagyon különbözőek (3.-4.-5. ábra). Mivel az eszköz oldalt nem modelleztük, így a valós kép a profitok tekintetében más lehet, hiszen az eszköz-forrás menedzsment szintén hatással lehet az eredményre.

Az elemzésünk alapján elmondható, hogy a profitszintek közötti különbözet az átmenetkor átértékelési különbözetként a tőkében jelenik meg egyszeri hatás formájában.
2. ábra: A teljes portfólió nyereségének hosszú távú alakulása

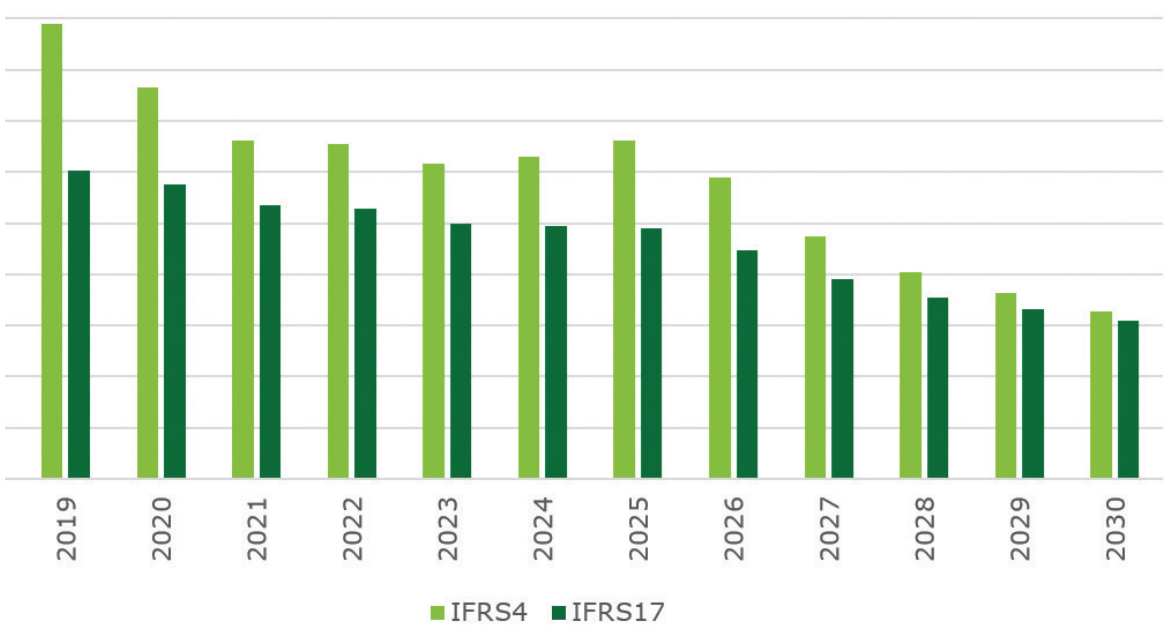

Forrás: Deloitte pénzügyi hatáselemzés biztositási portfólión

3. ábra: Vegyes biztosítások nyereségének hosszú távú alakulása

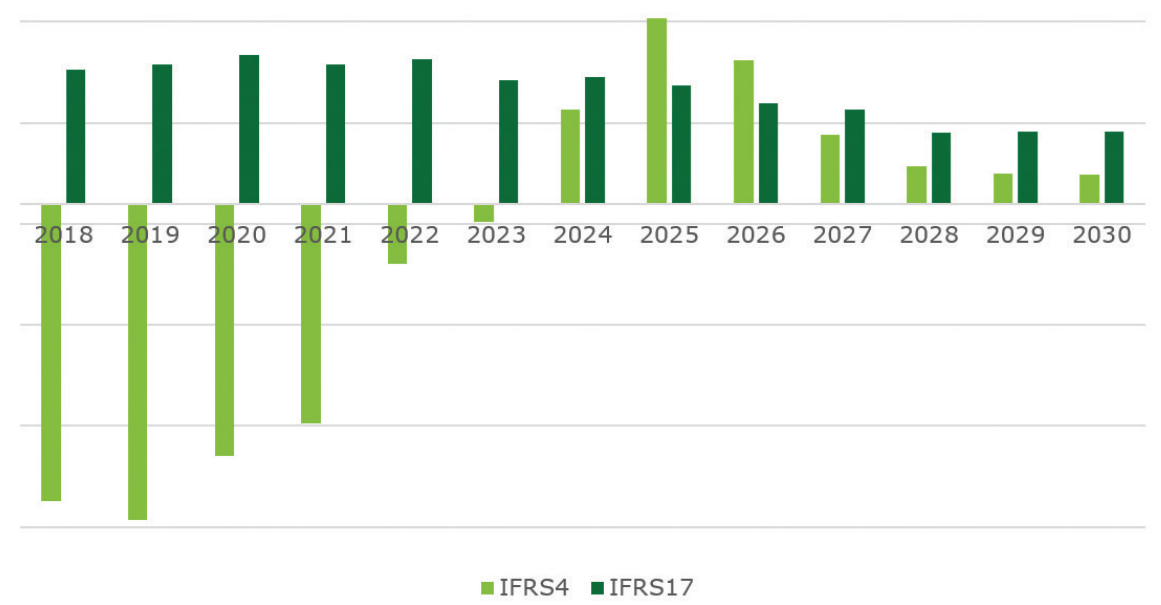

Forrás: Deloitte pénzügyi hatáselemzés biztositási portfólión 


\section{4. ábra: Kockázati biztosítások nyereségének hosszú távú alakulása}

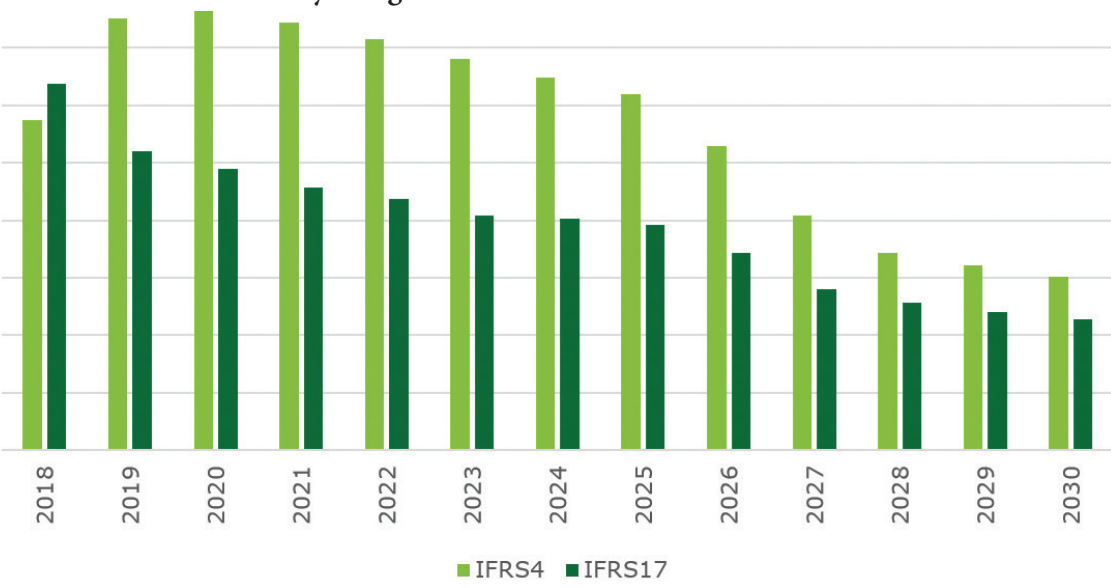

Forrás: Deloitte pénzügyi hatáselemzés biztositási portfólión

5. ábra: UL biztosítások nyereségének hosszú távú alakulása

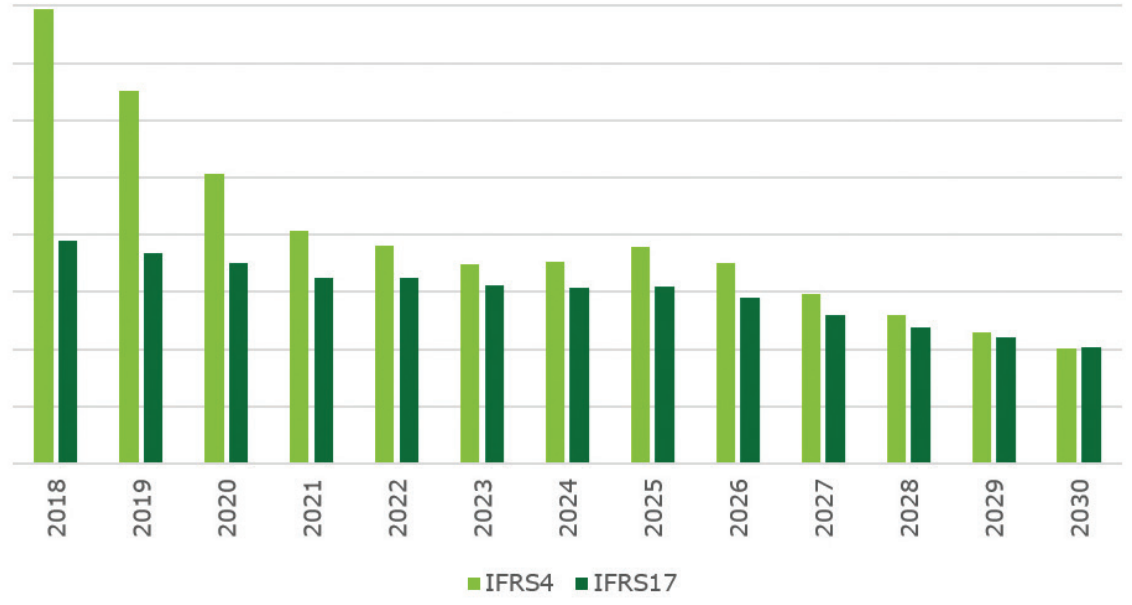

Forrás: Deloitte pénzügyi hatáselemzés biztositási portfólión

\section{CSM alakulása}

Mindhárom termék esetében megállapítható, hogy az eredmény alakulása az évek során kiegyensúlyozott, nincsenek benne nagy kilengések (6. ábra). A CSM változása nagyban függhet a választott fedezeti egységektől és az allokációs módszertől. Jelen esetben a fedezetben levő szerződések számát használtuk egy kohorsz fedezeti egységeinek meghatározásához, valamint a CSM allokációjához.

\section{6. ábra: CSM hosszú távú alakulása a három modellezett termék esetében}

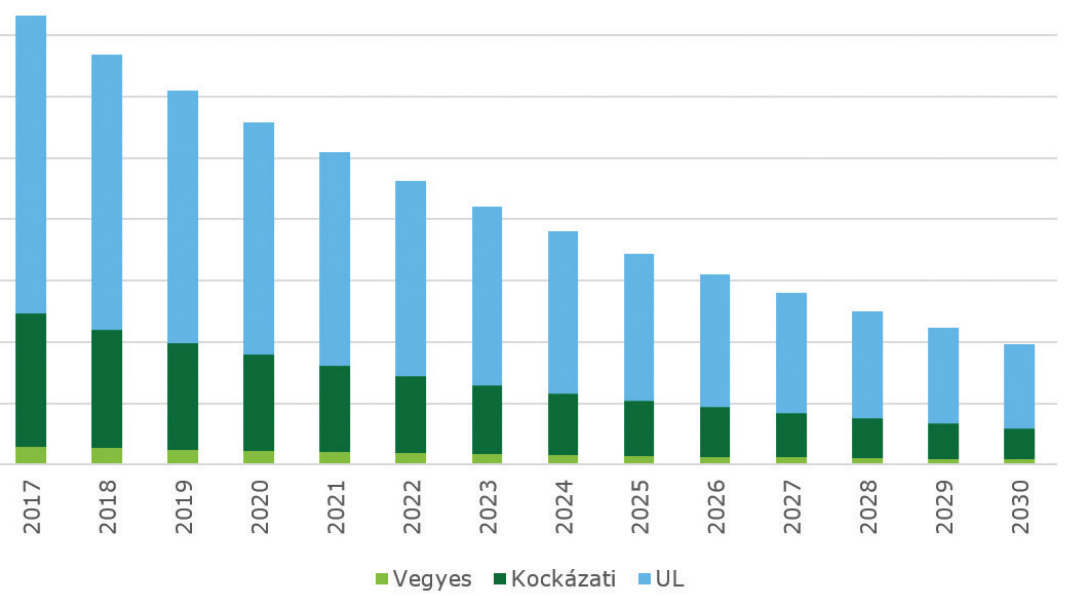

Forrás: Deloitte pénzügyi hatáselemzés biztositási portfólión

A CSM éven belüli alakulásának szemléltetéséhez a vegyes biztosítások 2017. évi kohorszára vonatkozó változásokat mutatjuk be a 7. ábrán.

7. ábra: CSM 2017 és 2018 közötti alakulása vegyes biztositás esetében
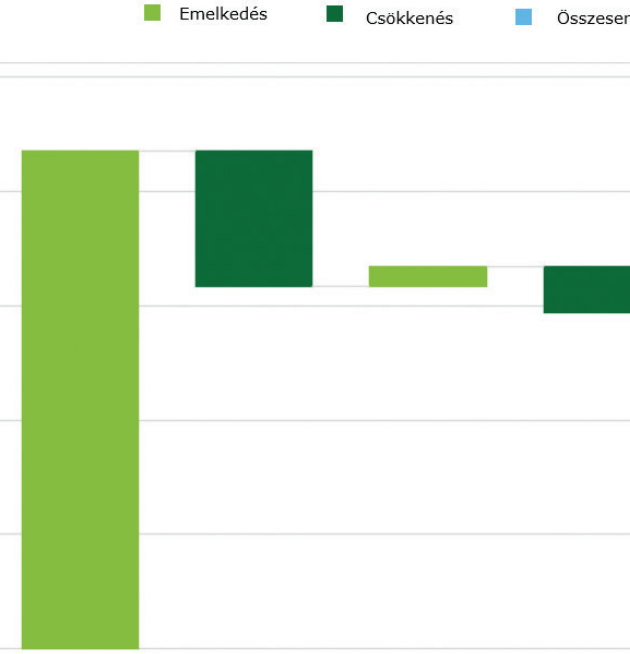

Nyit $\operatorname{csm}$

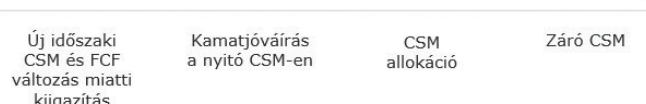

Forrás: Deloitte pénzügyi hatáselemzés biztositási portfólión 
A pénzügyi hatáselemzések során számos egyéb aspektusra is ki lehet térni, például még érdekes lehet az értékelési módszer kiválasztása vagy az egyéb átfogó jövedelem alkalmazásának lehetősége. A hatáselemzés egyik legfontosabb hozadéka véleményünk szerint, hogy átfogó képet kapunk a vizsgált állomány jelenlegi helyzetéről, de ami még talán enné is hasznosabb, hogy az esetlegesen alkalmazandó egyszerüsítések szükségességét feltárja.

A cikkünkben bemutatott üzleti és pénzügyi hatások és felvetett problémák alapján látható, hogy az IFRS 17 követelményeire történő sikeres felkészüléshez elengedhetetlen egy időben elkészített implementációs terv a biztosítók számára. Az alkalmazott módszerek meghatározása és alapos alátámasztása mellett az IT erőforrások tervezése lesz az egyik kulcskérdés. Kezdeti lépésként a biztosítók jelenlegi helyzetének, múködésének megismerése, a Standard hatásainak elemzése javasolt ahhoz, hogy valóban elégséges ido álljon rendelkezésre az IFRS 17 Standard bevezetését megelőző felkészülésre.

\section{HIVATKOZÁSOK}

${ }^{1}$ Granularitási szint alatt a biztosítási szerződésállomány aggregációs szintje értendő, azaz hogy mennyire részletesen van

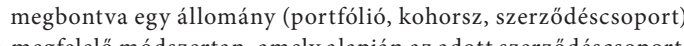

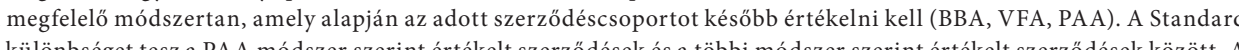
PA A esetében a a

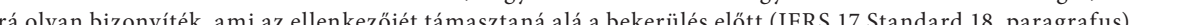
'Egy kohorszba csak olyan szerződések tartozhatnak, amelyek kibocsátása között egy év vagy annál kevesebb idő telik el. (IFRS 17 Standard paragrafus 22).

"Contractual Service Margin - CSM

${ }^{5}$ Loss Component - LC

${ }^{6}$ Feltéve, hogy a viszontbiztosító részéröl a szerződés nem felmondhatò

'IFRS 17 Standard 34. paragrafusának viszontbiztositási szerződésekre vonatkozó interpretációja a Transition Resource Group megbeszéles (2018. februarr 6.) alapján

BBIFRS 17 Standard 63. paragrafusa szerint.

${ }^{9} \mathrm{~A}$ befektetési elemek levalasztásara vonatkozó feltételrendszert az IFRS 17 Standard B31-B32. paragrafusai, a szolgáltatási elemek leválasztására vonatkozó szabályokat pedig az IFRS 17 Standard B33-B35. paragrafusai tartalmazzá ${ }^{10}$ Transition effect

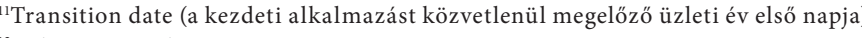

Loss Statement

${ }^{14} \mathrm{Fully}$ retrospective approach, modified retrospective approach, fair value approach

${ }^{16}$ Balancing item

${ }^{17}$ General Measurement Model - GMM

${ }^{19}$ Liability Adequacy Test - LAT

\section{IRODALOMJEGYZÉK}

IASB: IFRS Standards - IFRS 17 Insurance contracts (2017)

ntum - Insurer's preparation for the new IFRS accounting rules Defte/global/Documents/Financial-Services/InsIFRS/gx-fsi-Global\%20 0Survey\%202013.pdf

etoltes: 2018.08.10

Online:

https://www.iasplus.com/en/publications/global/surveys/2018-insurance-survey/fil 